\title{
IAMJ
}

INTERNATIONAL

AYURVEDIC

MEDICAL JOURNAL

\section{A REVIEW ON TOXICITY OF GUNJA (ABRUS PRECATORIUS)}

\author{
Praveen Kumar"1, Manish Rajak², Jai Kumar Singh ${ }^{3}$ \\ ${ }^{* 1,2}$ Post Graduate Scholar, Agada Tantra Evam Vidhi Vaidyaka \\ ${ }^{3}$ Professor \& H.O.D, Agada Tantra Evam Vidhi Vaidyaka \\ Government Ayurvedic College, Patna, Bihar, India
}

Corresponding Author: ayushpk5@gmail.com

https://doi.org/10.46607/iamj2309072021

(Published Online: July 2021)

Open Access

(C) International Ayurvedic Medical Journal, India 2021

Article Received: 23/06//2021 - Peer Reviewed: 24/06/2021 - Accepted for Publication: 25/06/2021

\section{Check for updates}

\section{ABSTRACT}

Gunja (Abrus precatorius Linn.) is a toxic plant which is described in various Samhita and other Ayurvedic texts. In Sushruta Samhita Vishaja dravyas are classified into Sthavara, Jangama and Kritima Visha. Gunja is mentioned in Sthavara Visha. In Sthavara Visha it is mentioned under Moolaja Adhisthan, which is one of the ten Adhisthan of Sthavara Visha. According to Rasa Tarangani Sthavara Visha are further divided into Mahavisha and Upavisha. Gunja is mentioned in Upavisha which is less potent toxic than Mahavisha. All parts of the plant are toxic, but the most toxic part is the seed which contains the active principle abrin. According to the modern concept, it is an irritant organic poison. In the Ayurvedic concept, if toxic plants are used after Shodhana process, they are useful in various types of diseases. The main aim of this study is to collect all the information related to Gunja and its toxicity.

Keywords: Gunja, Visha, Toxicity, Abrin, Shodhana

\section{INTRODUCTION}

Agada Tantra (1) is a branch of Astang Ayurveda that broadly describes the origin and types of Visha, its symptoms and management. Acharya Sushruta in the $3^{\text {rd }}$ Chapter (Jangam-Visavijaniya Adhyaya) of Kalpasthana, defined Visha (Poison) as: - Because of producing visada, it became known as Visha (2). In 
the modern concept Poison (3) can be defined as a substance that, when administered in any way, can act deleteriously on the body. A poison can be a solid, liquid or gas and can be inhaled, injected, or ingested.

Visha is classified into three types (4) viz. Sthavara Visha, Jangama Visha, Kritrima Visha

Gunja is a plant poison that has mentioned in Ayurveda under the Sthavara Vanaspatic Visha. Acharya Sushruta classified Gunja under MoolaVisha (5). In Bhavprakasha Nighantu it is mentioned under Guduchyadi varga, and other Rasashastra texts mentioned it under Upa-Visha $(6,7)$ which is less potent toxic than Mahavisha. According to modern, it is an irritant organic vegetable poison (8) belonging to the family Leguminosae. The botanical name of Gunja is Abrus precatorius Linn. Abrus precatorius known commonly as Rosary Pea, Jequirity bean, Indian bead, Buddhist Rosary bead, Seminole bead, Prayer bead, Jungle bead, Crab's eye, Weather plant, Love bean, Lucky bean, Ojo de pajaro, Indian liquorice (9). It is a slender climbing plant found all over India. Though all parts of the plant are poisonous, the most toxic part is the seed which contains the active principle abrin. The seeds of Gunja very similar in weight in older times Indians used to measure using these seeds and the measure were called Ratti (10).

General Description: It is a tropical, ornamental, twining, woody vine which grows to a height of 10 20 feet when supported by other plants. It has slender, tough branches with 5 to $10 \mathrm{~cm}$ long compound leave bearing 10-20 pairs of leaflets (11). Leaves are alternate, opposite, pinnately divided into small oblong leaflets. The leaves are like tamarind trees and sweet. Flowers are pink, purple, or white and borne in clusters. The distinctive part of the plant is the seed which is oval and has an attractive hard glossy outer shell that is usually scarlet red with a black centre. The seeds are present inside fruit pods, each containing 3 to 5 seeds. The pods split open when ripe. The pod is a legume (pea-shaped pod) and is about $3 \mathrm{~cm}$ long. The seeds are of the size of small peas, approx $0.85 \mathrm{cms} \times 0.65 \mathrm{cms}(8 \mathrm{~mm} \times 6 \mathrm{~mm})$ in size, its average weight is $110 \mathrm{mg}$. The beautiful red coloured seeds are egg-shaped having a black spot at one end. Rarely the seeds may be coloured white with black spots or maybe all white, black, yellow, or blue (12).

Vernacular Names (13): Sanskrit: Gunja, Raktika, Kakananti, Tamrika, Hindi: Ratti, Ghunghuchi, English: Indian liquorice, Jequirity, Rosary Pea, Urdu: Ghongcha, Ratti, Marathi: Gunjha, Telugu: Guriginja, Gujarati: Chanothi

\section{Types of Gunja:}

It is of two types-

A. Rakta Gunja (red colour of seed variety)

B. Sweta Gunja (white colour of seed variety)

Classical Categorisation (14):

- Sushruta - Moola Visha

- Kaiyadeva Nighantu - Oshadhi Varga

- Dhanvantari Nighantu - Karveeradi Varga

- Bhavaprakasha - Guduchyadi Varga, Upavisha

- Rajanighantu - Guduchyadi Varga

Rasa Panchaka:

- Rasa: Tikta, Kasaya

- Guna: Laghu, Ruksha

- Veerya: Usna

- Vipaka: Katu

- Karma: Kaphavatahara, Vrisya, Balya

Toxic part: Seeds, root, leaves.

But the most toxic part is a seed.

Chemical constituents: The seeds contain an active principle known as Abrin, a toxalbumin like ricin and its action resembles that of viperine snake venom (15). In addition, the Gunja seeds contain some poisonous proteins- abrine, N-methyl tryptophane, abraline (a glucoside), a lipolytic enzyme, abrussic acid, haemagglutinin and some urease.

Mode of Action: Abrin is a powerful gastrointestinal toxin and one of its polypeptide chains (B) binds to the intestinal cell membrane, while the other chain (A) enters the cytoplasm. Once in the cell, the A chain acts on the 60S ribosomal subunit, preventing 
binding of elongation factor 2 , thus inhibiting protein synthesis and leading to cell demise (16).

\section{Clinical features (17):}

\section{Ingestion of seeds or extract:}

When the seeds are swallowed raw or after cooking, they are not poisonous. Seeds must be crushed or chewed for harmful effects to occur.

Ingestion of seeds or extract causes:

a. Severe irritation of upper GIT, Abdominal pain, Nausea, Vomiting, Bloody diarrhoea, Rectal bleeding

b. Weakness, Cold perspiration, Trembling of the hands.

c. Weak rapid pulse, Tachycardia

d. Headache, Dilated pupils, Hallucinations, Drowsiness, Tetany and Circulatory collapse
2. Injection of the extract under the skin causes:

a. Painful inflammation, Oedema, Necrosis, and Oozing of haemorrhage fluid from the puncture site.

b. Tetanic convulsion and cerebral Oedema

c. Cardiovascular manifestation (like Snake bite), Arrythmia, Circulatory collapse, Irregular Pulse

d. Hemolysis, Oliguria and Uraemia

Fatal dose: $90-120 \mathrm{mg}$ by injection, 1-2 crushed seeds by mouth

Fatal Period: 3-5 days

Signs \& Symptoms: As per Ayurveda

Gunja poisoning is manifested by:

Daurbalya (Weakness), Rakta Srava (Bleeding),

Tandra (Fatigue), Moha (Stupor), Gatra Vrana (Ulceration)

\section{Differential diagnosis (18):}

Table 1: Differential diagnosis of Abrin Toxicity

\begin{tabular}{|l|l|l|}
\hline Features & Abrin & Viper \\
\hline a. $\quad$ History & Inj. Abrin & Viper bite \\
\hline b. $\quad$ Fang mark & Not Present & Present \\
\hline c. $\quad$ Fragment of Abrin & Found & Not found \\
\hline d. $\quad$ Local hemorrhagic oozing & Mild & Severe \\
\hline e. $\quad$ BT/CT & Average & Increases \\
\hline f. $\quad$ Systemic bleeding & Not found & Often found \\
\hline g. $\quad$ Subconjunctival bleeding & Not found & Often found \\
\hline
\end{tabular}

\section{Management of Toxicity:}

\section{A. Ayurvedic Treatment:}

1. Meghanada (Tanduliya) Swarasa (19) along with Sarkara (Sugar) should be consumed and followed by gulping of milk. This is a prescription for poisoning due to Gunja.

2. Uses of antidote like- Madhu-Sarkara yukta Grithpana, Haritaki Kashaya, Aphim, Belladona, Karpoora, Gunja, Tobacco

3. Give cow's milk with sugar.

B. Modern Treatment:

1. Resuscitation: Monitor and maintenance of $\mathrm{ABC}$ (Airway, Breathing \& Circulation)

2. Removal of unabsorbed Poison:

a. If the Patient is conscious- Induced emesis.

b. If Patient is unconscious- Mild purgation with stomach wash with $\mathrm{KMno}_{4}$ Solution- 1:1000
3. Removal of absorbed Poison- Forced diuresis.

4. Excision of the local part containing the sui or sutari may lead to uneventful recovery of the animal or the patient.

5. Anti-abrin an antiserum is to be used with success as treatment in Abrus poisoning.

6. Supportive measures with special emphasis on rehydration. Close attention should be given to haematological parameters.

7. Alkalinisation of the urine probably has a role in preventing the crystallization of haemoglobin and should be considered in severe poisoning.

8. Occular exposure necessitates copious irrigation with running water for at least 15 minutes.

9. Other symptomatic measures are to be taken as per requirement. 


\section{Post-mortem appearances:}

\section{External:}

- Injected poison: - Inflammation, swelling, oozing, wound necrosis etc (20)., Fragments of sui are usually found in the wound (21).

\section{- Ingested poison: - Not specific}

Internal:

- Injected poison: - Not specific

- Ingested poison: - Inflammation and congestion with erosion, submucous haemorrhage in GIT

\section{Medico- legal Importance:}

1. Accidental poisoning: Common

- In children who, out of curiosity, chew beautiful attractive seeds and

- Due to overdose when taken as a birth control pill.

2. Suis is used to kill cattle either to produce cheap hides or for revenge.

3. For homicide, the needle is kept between fingers and giving a slap which drives the needle into the body.

4. Abrus can be used as an arrow poison.

5. Malingers use powdered seeds to produce conjunctivitis.

\section{CONCLUSION}

Gunja (Abrus precatorius) is a toxic plant that is mentioned in various Samhitas of Ayurveda under Sthavara Vanaspatik Visha. It is also mentioned in Upavisha Varga. All parts of this plant are toxic, but the seed is the most toxic part. The seeds of Gunja plant are red and black, due to its colour it looks very attractive. Due to its abundant availability in villages and its attractive colour the children of villages play with these attractive seeds and so accidental poisoning is quite common among them. In the Ayurvedic concept, if toxic plants are used after proper purification methods i.e. Shodhana process, they are useful in various types of diseases. So, there is a necessity to have more knowledge regarding its toxic properties, its adverse effects and its Shodhana process, which plays a great role to reduce its toxicity.

\section{REFERENCES}

1. Srikantha Murty K.R. Sushruta Samhita of Acharya Sushruta. Vol. I. Varanasi; Chaukhamba Orientalia; 2017, 05p.

2. Srikantha Murty K.R. Sushruta Samhita of Acharya Sushruta. Vol. II. Varanasi; Chaukhamba Orientalia; 2017, 428p.

3. Basu Rabindra. Fundamentals of Forensic Medicine and Toxicology. 3rd edition. Kolkata; Books and Allied (P) Ltd; 2015. 403p.

4. Tripathi Dr. Brahmanand. Astanga Hrdyam of Srimadvagbhata. Delhi; Chaukhamba Sanskrit Pratisthan; 2011, 1145p.

5. Srikantha Murty K.R. Sushruta Samhita of Acharya Sushruta. Vol. II. Varanasi; Chaukhamba Orientalia; 2017, 419p.

6. Chunekar Dr. K.C. edited by Dr. G. S. Pandey. Bhavaprakash Nighantu of Sri Bhavamisra. Varanasi; Chaukhambha Bharati Academy; 2009, 354p.

7. Sharma Sri Sadanand. edited by Pt. Kashinath Shastri. 11th edition. Delhi; Motilal Banarasidas; 2009, 727p.

8. Pillay Dr V.V. Modern Medical Toxicology. 4th edition. New Delhi; Jaypee Brothers; 2013, 127p.

9. Pillay Dr V.V. Modern Medical Toxicology. 4th edition. New Delhi; Jaypee Brothers; 2013, 127p.

10. Banjare Nitu, Inchular SR, Kaushik Yuvraj, Gunja (Abrus precatorius Linn.) A precious toxic plant: A review. JMPS 2020; 8(4); 304-307

11. Pillay Dr V.V. Modern Medical Toxicology. 4th edition. New Delhi; Jaypee Brothers; 2013, 127p.

12. Karmakar R. N. Forensic Medicine and Toxicology. 5th edition. Kolkata; Academic Publishers; 2018. 907p.

13. Chunekar Dr. K.C. edited by Dr. G. S. Pandey. Bhavaprakash Nighantu of Sri Bhavamisra. Varanasi; Chaukhambha Bharati Academy; 2009, 354p.

14. https://www.easyayurveda.com/2015/09/12/rosarypeaabrus-precatorius/\#classical_categorisation\#dated 1406-2021 time 13:11 IST

15. Karmakar R. N. Forensic Medicine and Toxicology. 5th edition. Kolkata; Academic Publishers; 2018. 908p.

16. Pillay Dr V.V. Modern Medical Toxicology. 4th edition. New Delhi; Jaypee Brothers; 2013, 128p.

17. Kumar Ajay. TextBook of Forensic Medicine. 2nd edition. Sirour; Avichal Publishing Company; 2019. 366p. 
18. Charak Dr Sandeep. Textbook of Agad Tantra Evam Vyavaharayurved. 1st edition. Jaipur; Jagdish Sanskrit Pustakalaya; 2020. 54p.

19. Achal Dr. Ayodhya Prasad. Textbook of Ayurvedic Toxicology. 2nd edition. Varanasi; Choukhamba Surbharti Prakashan; 2020. 96p.

20. Kushwaha Dr Sandeep and Choudhari Dr Sheetal, Review of Gunja and its Toxicity (Abrus precatorius). Ejpmr, 2018 (11), 215-217

21. Bhat K. Dr Shobha. A Textbook of Agada Tantra. 1st edition. Varanasi; Choukhambha Orientalia; 2018. $129 \mathrm{p}$

\section{Source of Support: Nil Conflict of Interest: None Declared}

How to cite this URL: Praveen Kumar et al: A Review On Toxicity Of Gunja (Abrus Precatorius). International Ayurvedic Medical Journal \{online\} 2021 \{cited July 2021\} Available from: http://www.iamj.in/posts/images/upload/1469_1473.pdf 